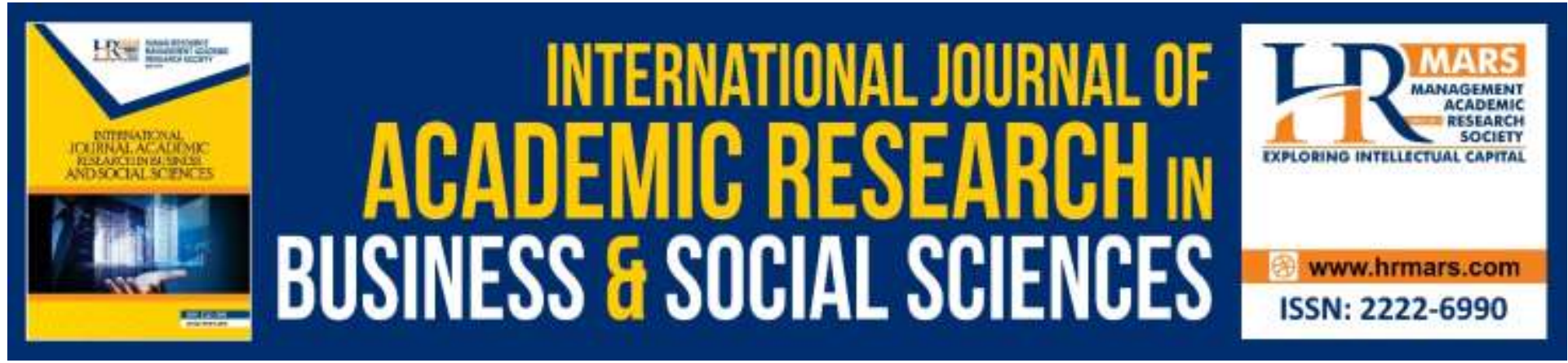

\title{
Diamond Export and Economic Growth in Angola
}

\section{Leonilda Da C Tomas De Almeida}

To Link this Article: http://dx.doi.org/10.6007/IJARBSS/v9-i9/6382

DOI: $10.6007 /$ IJARBSS/v9-i9/6382

Received: 09 July 2019, Revised: 15 August 2019, Accepted: 30 August 2019

Published Online: 25 September 2019

In-Text Citation: (Almeida, 2019)

To Cite this Article: Almeida, L. D. C. T. D. (2019). Diamond Export and Economic Growth in Angola. International Journal of Academic Research in Business and Social Sciences, 9(9), 926-934.

Copyright: (C) 2019 The Author(s)

Published by Human Resource Management Academic Research Society (www.hrmars.com)

This article is published under the Creative Commons Attribution (CC BY 4.0) license. Anyone may reproduce, distribute, translate and create derivative works of this article (for both commercial and non-commercial purposes), subject to full attribution to the original publication and authors. The full terms of this license may be seen

at: http://creativecommons.org/licences/by/4.0/legalcode

Vol. 9, No. 9, 2019, Pg. 926 - 934

http://hrmars.com/index.php/pages/detail/IJARBSS

JOURNAL HOMEPAGE

Full Terms \& Conditions of access and use can be found at http://hrmars.com/index.php/pages/detail/publication-ethics 


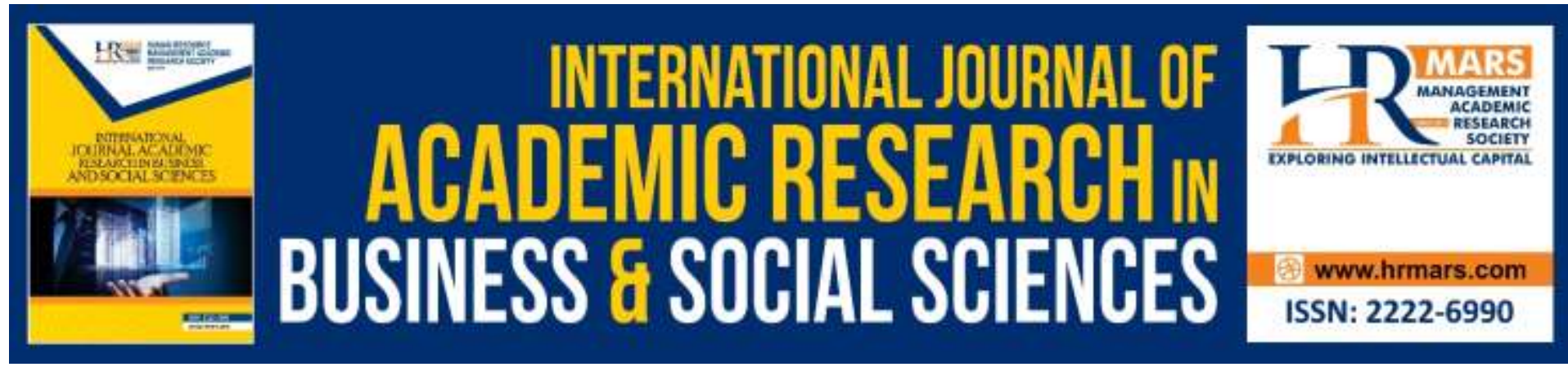

\title{
Diamond Export and Economic Growth in Angola
}

\author{
Leonilda Da C Tomas De Almeida
}

College of Economics and Management, Nanjing University of Aeronautics and Astronautics, Nanjing 210016, China

\begin{abstract}
This study is an attempt to examine the relationship between diamond export and economic growth in Angola during the period of 2001-2018. Based on the estimation of the autoregressive model of distributed lags, the study concludes that diamond exports and economic growth are cointegrated. In addition, there is a positive one-way causality in diamond exports for long-term economic growth, which supports energy infrastructure investment policies. On the other hand, the absence of some reverse causality of economic growth for diamond production and exports, highlights due to Angola's heavy reliance on foreign demand for its oil to drive economic growth. Thus, in turn, policymakers must also consider diversifying the economy into other growing sectors in order to mitigate the impact of global economic shocks. The diamond is the second most important resource in Angola, so the government has been using it as a means of diversifying the economy in order to balance the less good economic situation that the country lives.
\end{abstract}

Keywords: Diamond Export, Economic Growth, ARDL, Granger Causality, ECM.

\section{Introduction}

Mining in Angola is an activity with great economic potential, as the country has one of the largest and most diversified mining resources in Africa. Angola is that the third largest diamond producer in continent and has solely explored four-hundredth of the diamond, however has had problem attracting foreign investment as a result of corruption, human rights violations and diamond smuggling. Diamond production increased 30\% in 2013 and Endiama, Angola's national diamond company, expects production to increase from $8 \%$ in 2014 to $10,000,000$ carats $(2,000 \mathrm{~kg})$ annually. The government is making an attempt to draw in foreign corporations to the provinces of Bie, Malanje and Uige. With the end of the civil war in 2002, political and economic stability in the following years made Angola one of the fastest growing countries in the world. The largest growth sector was the oil sector, which made the Angolan economy heavily dependent on this resource. The problems posed to the country by the sharp fall in oil prices in 2015 corroborated this fact. Therefore, government authorities have initiated strategies to address this structural vulnerability by investing in other sectors such as agriculture, industry, trade and other services. In the first instance, the mineral sector, in particular the diamond subsector, is the main focus as the second foundation of this economy. Note that although oil and diamonds are at the base of the Angolan economy, both still have very different contributions, with oil clearly dominant. 
Angolan diamonds have been known for over one hundred years. They are famous for their high quality and high value, attracting buyers from all over the world from the giant De Beers (exclusive buyer for many decades) to the smallest. Angola has kimberlitic and alluvial diamond deposits. Many of these deposits are still awaiting development. Probably many other deposits are yet to be discovered following further research, given the enormous diamond potential of the Angolan territory (Chambel, Caetano \& Reis, 2013). Diamond prices in Angola vary depending on the company. Catoca Company (kimberlite): 109 to 117 USD/carat given Catoca (Chambel, Caetano, \& Reis, 2013); Lulo (alluvium, very close to the primary source) :> 2,500 USD/carat (Lucapa Diamond Company, 2016; Khalid, Pahi, \& Ahmed, 2016).

In this analysis, it is important to add that, according to 2015 data (Angola Economic Report, 2015), Angola is the world's fifth largest diamond producer, both in value and volume. However, in order to ensure the vitality and development of this subsector, new kimberlite mines need to be discovered and explored, as about $75 \%$ by volume of current production is based on the mature Catoca mine. This study investigates the short run and long run relationship between diamond export and economic growth in Angola for the period 20012018.

The study additionally makes an attempt to determine creator relation between these variables. In particular, whether there is unidirectional or bidirectional relationship between diamond export and economic growth using the autoregressive distributed lag (ARDL) approach to cointegration. (Mehlum, Moene, and Torvik, 2006).

\section{Data}

Data for the underlying variables, export demand and GDP, were obtained from various sources. Annual time series data were obtained from 2001 to 2018, considering data availability. National diamond export data in thousands of carats per day was obtained from the official website of the Ministry of Finance in Angola. And the gross domestic product data is in US dollar and these in turn were obtained from the World Development Indicators website. The graphical representation of the data is shown in Figures 1 and 2. Summary statistics are provided in Table 1. 
Table 1: Descriptive statistics

\begin{tabular}{lcc}
\hline & Diamond Export & GDP \\
\hline Mean & $1.14 \mathrm{E}+09$ & 0.000833 \\
Median & 23280.37 & $3.73 \mathrm{E}+09$ \\
Maximum & 634331.5 & $2.07 \mathrm{E}+12$ \\
Minimum & 648994.6 & $2.17 \mathrm{E}+12$ \\
Std. Dev. & 415113.5 & $1.35 \mathrm{E}+12$ \\
Skewness & 0.204331 & 0.012686 \\
Kurtosis & 1.848732 & 1.782372 \\
& & \\
Jarque-Bera & 1.057133 & 1.050641 \\
Probability & 0.589449 & 0.591366 \\
\hline \hline Observations & $\mathbf{1 7}$ & $\mathbf{1 7}$
\end{tabular}

Source: Author's calculations using E-views 10

\section{Empirical Methodology}

The document aims to examine the relationship between diamond exports and short- and long-term economic growth in Angola. There are several econometric techniques to examine the short- and long-term relationship between variables such as cointegration models, autoregressive vectors (VAR) and ARDL model. But this study opted for the ARDL limit test model proposed by Pesaran et al. (2001) to estimate short- and long-term coefficients. The ARDL model is a general dynamic specification that uses the dependent variable offsets and the lagged and contemporary values of the explanatory variable through which short term effects can be estimated directly, and the long-term equilibrium relationship can be indirectly estimated. estimated (Altinay, 2007; Gosh, 2009). The second advantage, according to Pesaran et al. (2001) is that this model provides reliable results wherever the sample is extremely tiny. The third advantage of the model is that it automatically assigns the best delay value to a specific variable that is suitable for a model. The ARDL technique involves estimating the subsequent unrestricted error correction model:

$$
\begin{aligned}
& \Delta G D P_{\mathrm{t}}=\alpha_{0}+\sum_{i=1}^{m} \beta \Delta G D P_{\mathrm{t}-1}+\sum_{i=1}^{n} \Psi \Delta D E_{\mathrm{t}-1}+\emptyset_{1} \mathrm{GDP}_{\mathrm{t}-1}+\emptyset_{2} \mathrm{P}_{\mathrm{t}-1}+\varepsilon_{1 \mathrm{t}} \\
& \Delta D E_{\mathrm{t}}=\alpha_{0}+\sum_{i=1}^{m} \beta \Delta D E_{\mathrm{t}-1}+\sum_{i=1}^{n} \Psi \Delta G D P_{\mathrm{t}-1}+\theta_{1} \mathrm{DE}_{\mathrm{t}-1}+\theta_{2} \mathrm{GDP}_{\mathrm{t}-1}+\varepsilon_{2 \mathrm{t}}
\end{aligned}
$$

The null hypothesis of non-cointegration between the variables in Eq. (1) is H0: $\phi 1=\phi 2=0$ is tested against an alternative H0: $\varphi 1 \neq \varphi 2 \neq 0$ denoted as FY (Y, OP). Similarly, for Eq. (2), HO: $\theta 1=\theta 2=0$ is tested against an alternative $\mathrm{H1}: \theta 1 \neq \theta 2 \neq 0$ and denoted as FOP (OP, Y). Two sets of critical F values were provided by Pesaran et al. (1999) and Pesaran et al. (2001) with one set assuming all variables in the ARDL model are I (0) (lower limit) and another assuming all variables are I (1) (upper limit). If the computed $\mathrm{F}$ statistic is left out, a conclusive decision can be made without having to know if the underlying variables are I (0) or I (1). On the other hand, if the computed $F$ statistic is within the critical range, the inference remains inconclusive. Under such circumstances, the order of integration of the variables of interest should be verified using Johansen and Juselius (1990) procedures to detect cointegration (Gosh, 2009; Onafowora and Owoye, 2014). 


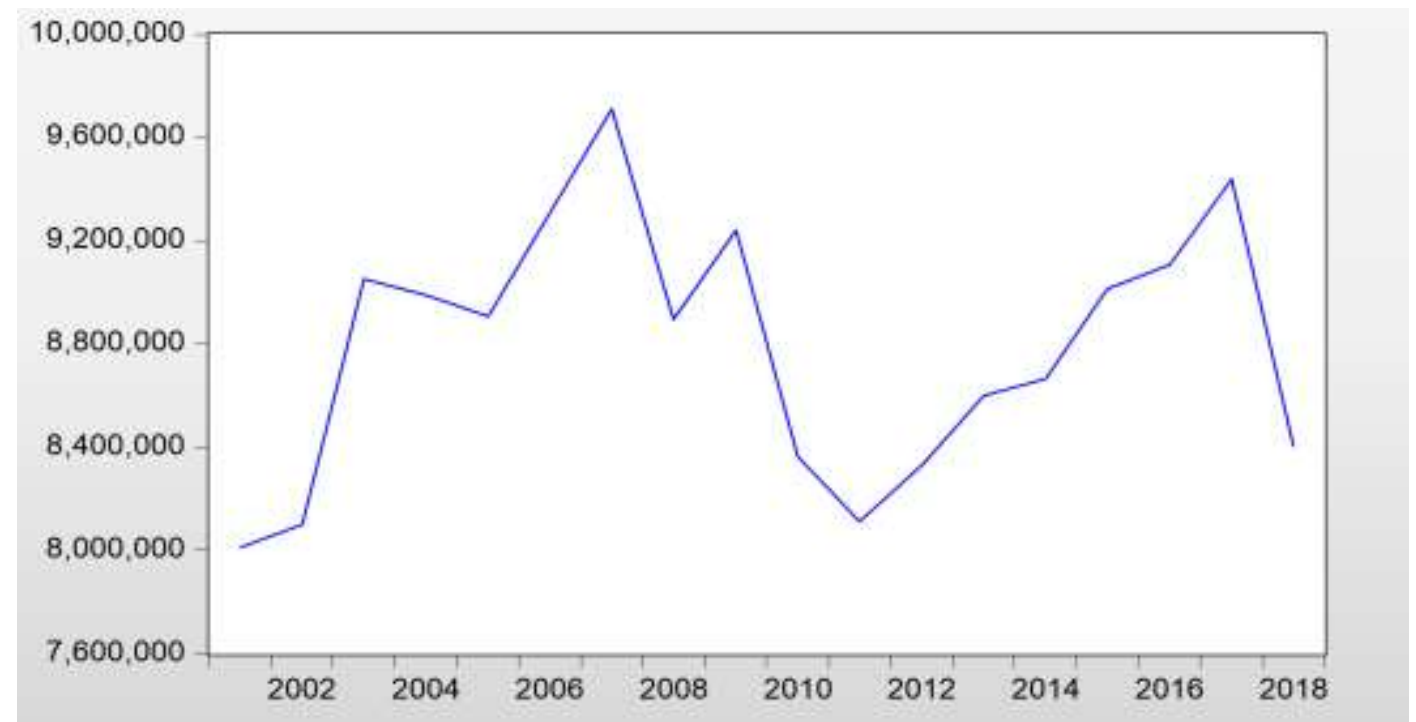

Figure 1: Diamond export (million carats)

Source: Author's calculations using E-views 10

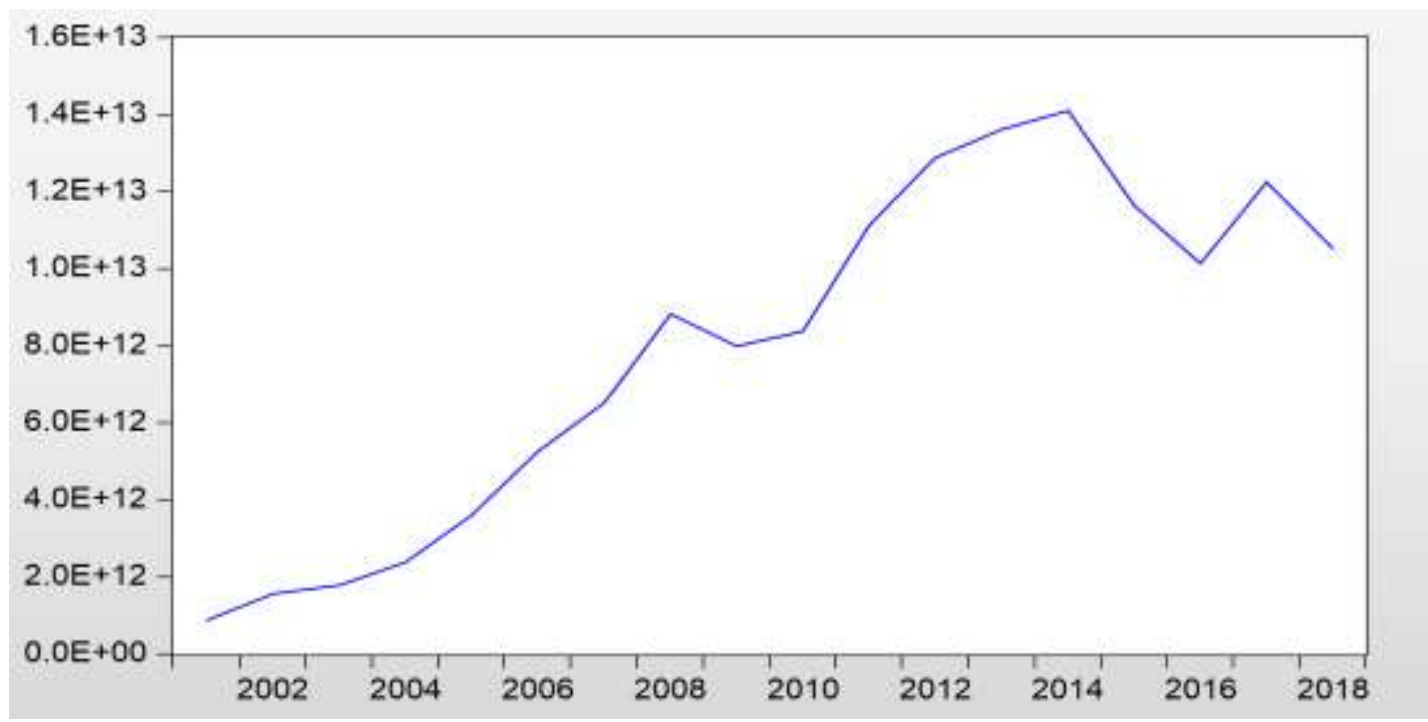

Figure 2: Gross domestic product (billion US dollars)

Source: Author's calculations using E-views 10

\section{Granger Causality Test}

Granger's causality test is widely used to examine the causal relationship between variables. Engle and Granger (1987) showed whether series X and Y, for example, are individually I (1) and cointegrated, there would be a causal relationship at least going in one direction. The direction of causality can be detected by the long-term cointegration vector error correction model vectors. Following Gosh (2009), the study tests Granger causality by estimating the following equations:

$$
\begin{aligned}
& \Delta \mathrm{GDP}_{\mathrm{t}}=\beta_{10}+\sum_{\mathrm{i}=1}^{\mathrm{P}} \beta_{11 \mathrm{i}} \Delta \mathrm{GDP}_{\mathrm{t}-1}+\sum_{\mathrm{i}=1}^{\mathrm{P}} \beta_{12 \mathrm{i}} \Delta \mathrm{DE}_{\mathrm{t}-1}+\beta_{13} \mathrm{ECT}_{\mathrm{t}-1}+\varepsilon_{1 \mathrm{t}} \\
& \Delta D E_{t}=\beta_{20}+\sum_{i=1}^{P} \beta_{21 \mathrm{i}} \Delta \mathrm{DE}_{\mathrm{t}-1}+\sum_{i=1}^{P} \beta_{22 \mathrm{i}} \Delta \mathrm{GDP}_{\mathrm{t}-1}+\beta_{23} \mathrm{ECT}_{\mathrm{t}-1}+\varepsilon_{2 \mathrm{t}}
\end{aligned}
$$


Where $\beta$ s are parameters to be estimated, ECTs are the error correction terms resulting from long-term equilibrium relationship and $\varepsilon s$ are the serial uncorrelated error terms. The $F$ statistics on ECM lagged explanatory variables indicate the significance of causal effects in the short term. The t-statistics for lagged ECT coefficients indicate the importance of the longterm causal effect.

\section{Empirical Results}

Results indicate that cointegration is present when GDP or DE is used as the dependent variable. The $F$ statistics computed $F_{G D P}(G D P, D E)$ and $F_{D E}(D E, G D P)$ are out, implying the existence of a long-term relationship between the two variables.

Having established long term relationship, two more procedure steps is performed. In the first step, the ideal order of lag in the models is determined based on the Akaike information criterion (AIC), Hannan-Quinn criterion (HQ) and Schwarz criterion (SC). In the second step, the selected model is estimated using the ARDL specification in Eq. (1) and Eq. (2) Based on the AIC and HQ criteria, we find an ideal delay of 2 for Eq. (1) and 1 for the Eq. (2) SC selected an ideal delay of 1 for both Eq. (1) and Eq. (2) the estimated long-term coefficients, along with standard errors and ARDL (1.0) -based acceptance probabilities for Eq. $(1)$ and ARDL $(1,1)$ for Eq. (2) are shown in Table 3. Long-term elasticity of diamond export growth is 2.8 and statistically significant as an increase of $2 \%$ in diamond exports is associated with a $2.8 \%$ increase in GDP. The elasticity of long-term diamond export GDP growth is 0.48 and is not statistically significant at the $5 \%$ level.

\section{Granger Causality Test Results}

The results of cointegration and ARDL determine the existence or absence of a long-term relationship between variables (Export and GDP), but these methods do not indicate the direction of causality. Consequently, the Granger causality test is used to examine causal relationships. The following table shows the results of Granger Causal Relations based on Eq. (3) and Eq. (4). The F statistics on ECT lagged explanatory variables are not statistically significant at the $5 \%$ level, indicating that there is no causality in any short-term direction. The lagged ECT coefficient in the $\triangle$ GDPt equation is statistically significant, suggesting that the series is non-explosive and the long-term balance is attainable between economic growth and diamond exports. Thus, in the long run, it is Granger's unidirectional causality that stems from diamond exports and GDP growth.

Table 2: Bounds tests for cointegration

Critical Values of Bounds

\begin{tabular}{llll}
\hline F-Statistics Values & P-Value & I (0) & I (1) \\
\hline & $5 \%$ & 3.62 & 4.16 \\
\hline
\end{tabular}

$\mathrm{F}_{\mathrm{GDP}}(\mathrm{GDP}, \mathrm{DE})=1.744513$

$F_{D E}(D E, G D P)=2.59862$

Source: Author's calculations using E-views 10 
Table 3: Estimated long-run coefficients with standard errors and probabilities

\begin{tabular}{lclll}
\hline Dependent Variable GDP & \multicolumn{5}{l}{} \\
\hline Variables & Coefficient & Standard Error & t-Statistics & Probability \\
DE & 2.835846 & 6.143655 & 0.461589 & 0.6515 \\
Constant & $3.73 \mathrm{E}+13$ & $5.49 \mathrm{E}+13$ & 0.680173 & 0.5075 \\
& & & & \\
\hline Dependent Variable DE & & & & \\
\hline Variables & Coefficient & Standard Error & t-Statistics & Probability \\
GDP & $3.23 \mathrm{E}-08$ & $4.67 \mathrm{E}-08$ & 0.692175 & 0.5001 \\
Constant & 9.124043 & 436077.6 & 20.92298 & 0.0000
\end{tabular}

Source: Author's calculations using E-views 10

Note: Estimated long-run coefficients for GDP based on the ARDL $(1,0)$ model and for COP based on the ARDL $(1,1)$ model

Table 4: Granger Causality Test Results

\begin{tabular}{lll}
\hline Short-run & & \\
\hline Dependent Variable & $\Delta \mathrm{GDP}$ & $\Delta \mathrm{DE}$ \\
$\Delta \mathrm{GDP}$ & - & $1.91 \mathrm{E}-08$ \\
$\Delta \mathrm{DE}$ & 3.606659 & - \\
\hline Long-run & & \\
\hline Dependent Variable & $\Delta \mathrm{GDP}$ & $\Delta \mathrm{DE}$ \\
$\Delta \mathrm{GDP}$ & - & 0.590908 \\
$\Delta \mathrm{DE}$ & 0.127181 & - \\
\hline \hline
\end{tabular}

Source: Author's calculations using E-views 10

Note: Results based on F-statistics on lagged explanatory variable of the ECM

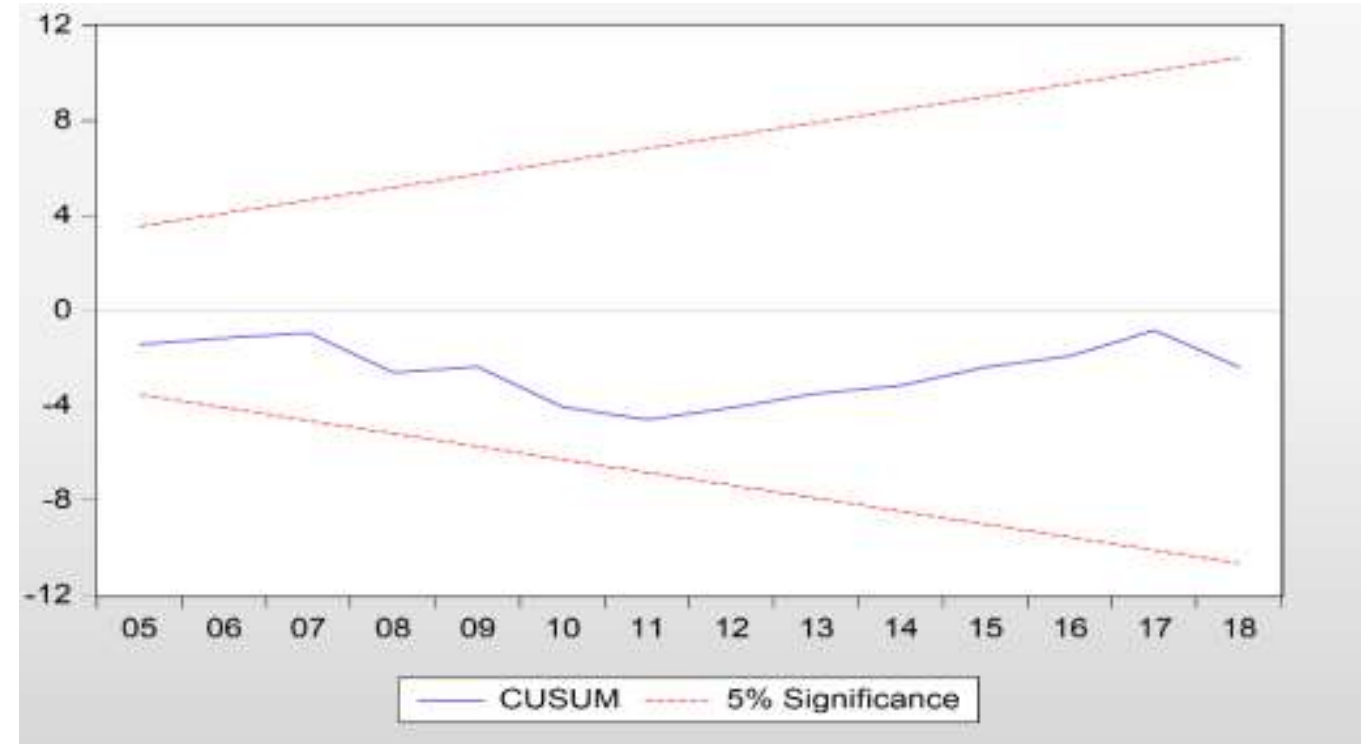

Figure 3: Cusum

Source: Author's calculations using E-views 10 


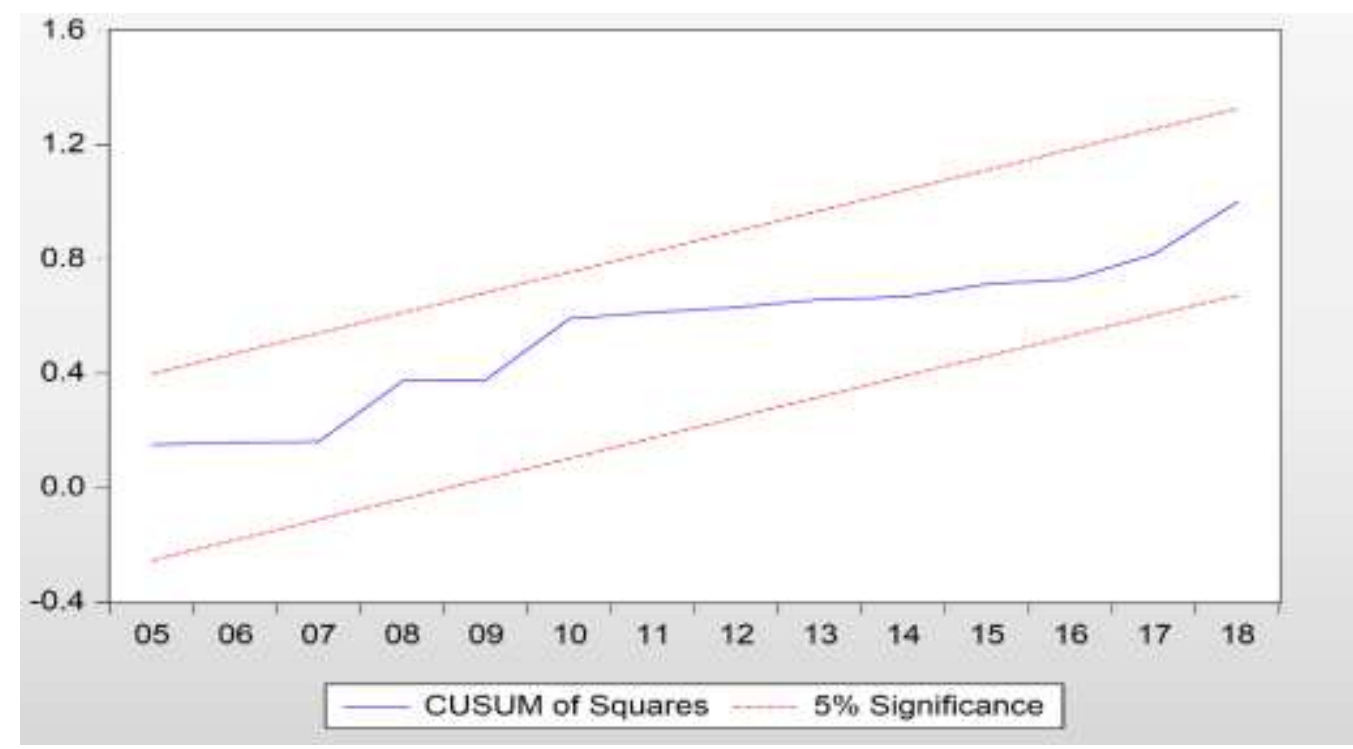

Figure 4: Cusum of squares

Source: Author's calculations using E-views 10

\section{Conclusion}

This study investigated the relationship of cointegration and causality between diamond exports and economic growth in Angola using the ARDL Model. Limit test results indicate that diamond exports and economic growth are cointegrated. Granger causality tests inferred from the error correction model reveal that there is unidirectional causality in diamond exports to long-term economic growth. Thus, policymakers in Angola should consider improving energy infrastructure and increasing diamond exports to achieve greater economic growth.

Considering the relatively peaceful history of the country and another feature that reveals the institutional quality and compares it with its counterpart in other countries, the success of the diamond is probably due to the higher institutional quality. Hence the conclusion to be drawn is that the existence of diamond resources seems to reinforce growth and development, either positively or negatively.

In this research, the use of the ARDL method for the short- and long-term relationship of Angola's daily exportation shows that there is a relationship between the variables and that diamond is a great potential for Angola's economic growth. As diamond represents Angoloa's second most important natural resource, it can help the Angolan authorities in their strategies to combat poverty, help fundraising, and help the country diversify its heavily oil-dependent economy.

\section{Acknowledgement}

The authors thank the editor and anonymous reviewers for their constructive and insightful comments that helped improve the paper. Usual disclaimers apply. 


\section{Corresponding Author}

Leonilda Da C Tomás De Almeida

College of Economics and Management

Nanjing University of Aeronautics and Astronautics, Nanjing 210016, China

Email: leonildadealmeida@gmail.com

\section{References}

Arnim, V. R., Prabheesh, K. P. (2013), Rebalancing through expenditure and price changes. International Review of Applied Economics, 27(4), 531-556.

Boschini A. D., Pettersson J., and Roine, J. (2003), Resource curse or not: A question of appropriability SSE/EFI Working paper series in economics and finance, No 534.

Glasure, Y. U., Lee, A. R. (1998), Cointegration, error-correction and the relationship between GDP and energy: The case of South Korea and Singapore. Resource and Energy Economics, 20, 17-25.

Khalid, N., Pahi, M. H., \& Ahmed, U. (2016). Loosing your best talent: Can leadership retain employees? The dilemma of the banking sector of Hyderabad Sindh, Pakistan: A mediation investigation. International Review of Management and Marketing, 6(3), 608-616.

Madrid, D., Ahmed, U., \& Kumar, R. (2019). Examining the Impact of Classroom Environment on Entrepreneurship Education: Case of a Private University in Bahrain. Journal of Entrepreneurship Education, 22(1), 1-8.

Mehlum, H., Moene, K., and Torvik, R. (2006), Institutions and the resource curse The Economic journal 116 Blackwell Publishing.

Olsson O. (2006a), Conflict diamonds Journal of development economics.

Olsson O. (2006b), Diamonds are a rebel's best friend The World Economy Blackwell Publishing.

Pesaran, H. M., Shin, Y., Smith, R. J. (1999), Pooled mean group estimation of dynamic heterogeneous panels. Journal of the American Statistical Association, 94(446), 621634.

Pesaran, M. H., Shin, Y., Smith, R. J. (2001), Bounds testing approaches to the analysis of level relationships, Journal of Applied Econometrics, 16, 289-326.

Sala-i-Martin, X., and Subramanian, A. (2003), Addressing the natural resource curse - an illustration from Nigeria National Bureau of Economic Research Working paper 9804 Cambridge.

Toman, M. A., Jemelkova, B. (2003), Energy and economic development: An assessment of the state of knowledge. Energy Journal, 24(4), 93-112.

United Nations Development Program (2004), Conflits armés en Republique Democratique du Congo - Le rôle des facteurs economiques et leçons pour la reconstruction.

United States General Accounting Office (2002), International trade - Critical issues remain in deterring conflict diamond trade Report to congressional requesters GAO-02 - 678.

World Bank. (2017), World Bank World Development Indicators. Washington, DC: World Bank. 